\title{
FINANCING CONSTRAINTS AND FIRM GROWTH IN EMERGING EUROPE
}

Sandra M. Leitner

\section{ABSTRACT}

The paper aims to shed light on the effects of different types of financing constraints on firm sales and employment growth in Emerging Europe before and after the onset of the financial crisis. It analyzes the group of emerging NMS-10 economies (plus Turkey) and the group of economically and financially lagging Western Balkan countries. The paper demonstrates that financing constraints significantly obstruct firm growth, particularly in the Western Balkan countries, which calls for policy intervention to ensure swifter job-rich growth and catching-up with the rest of Europe. It also emphasizes that particular firm characteristics are essential for growth in Emerging Europe and demonstrates that exporting only and innovating are recipes for faster firm growth, while importing only and a high foreign ownership share seriously retard firm growth. Finally, it stresses the importance of the particular institutional environment for firms to thrive.

Keywords: financing constraints, establishment growth, NMS-10, Western Balkans, financial crisis.

JEL Code: $L 25, D 22, D 53,016,057$.

\section{INTRODUCTION}

Alarmingly, the burgeoning empirical literature on the causes and effects of financing constraints finds considerable and robust evidence that financing constraints severely affect firm behavior, obstruct firm performance and greatly curb firm growth. ${ }^{1}$

Theoretically, the presence of financing constraints is ascribed to capital market imperfections such as non-negligible information asymmetries between entrepreneurs and uninformed outside investors. For instance, in the model of credit rationing developed by Stiglitz and Weiss (1981), imperfect information induces banks to resort to rationing credits instead of increasing the interest rate to maximize profits. Since the interest rate banks charge for credits also affects the riskiness of their pool of loans through an adverse selection effect and a negative incentive effect, higher interest rates would both attract riskier projects and induce debtors to realize projects with a generally lower probability of success but higher returns when successful. Hence, the on average higher riskiness of potential borrowers lowers overall profits for the banks and induces profit-maximizing banks to restrict the number of credits they grant.

Empirically, a quickly growing body of literature finds strong evidence of financing constraints, but also stresses that the prevalence and extent of such constraints strongly depend on specific firm characteristics. For instance, due to insufficient collateral and resources, smaller firms are more financially constrained

Sandra M. Leitner, $\mathrm{PhD}$

Vienna Institute for International Economic Studies

E-mail: sandra.leitner@wiiw.ac.at 
than larger ones (see, e.g., Angelini and Generale 2005; Beck, Demirgüç-Kunt, and Maksimovic 2006; Hadlock and Pierce 2010 or Winker 1999) or that due to the lack of relevant reputation and credit history, younger firms face stronger financing constraints (see, e.g., Beck, Demirgüç-Kunt, and Maksimovic 2006; Winker 1999 or Ferrando and Mulier 2013). Furthermore, due to the presence of and easier access to internal capital markets, financing constraints are lower among foreign-owned firms (see, e.g., Schiantarelli and Sembenelli 2000 or Beck, Demirgüç-Kunt, and Maksimovic 2006) or among firms that are part of a business group (see, e.g, Shin and Park 1999 or Beck, Demirgüç-Kunt, and Maksimovic 2006). Likewise, preferential treatment from state-owned financial institutions or generous budgetary support from the government also renders state-owned firms less financially constrained (see, e.g., Héricourt and Poncet 2007). Additionally, empirical evidence highlights that the macro-economic context matters and points to the decisive role of economic, financial and legal system development in alleviating funding obstacles (see, e.g., Beck, Demirgüç-Kunt, and Maksimovic 2003 and 2006 or Clarke, Cull, and Martinez Peria 2001).

These impediments to external funding are even more important in lagging economies, where access to financial markets is not only a crucial determinant of the growth and survival of firms, but, more importantly, of economic growth and catching-up processes with richer economies. In this context, the analysis pursues the following key objectives: first, it sheds light on the effects of financing constraints on firm growth for a rich sample of transition economies in Central, East and Southeast Europe. It analyzes the group of emerging Central and Eastern economies comprising all NMS-10 economies ${ }^{2}$ plus Turkey and the group of economically and financially lagging Western Balkan countries ${ }^{3}$. More importantly, it seeks to establish whether the growth-effects of financial constraints differ by level of economic development, and analyzes whether financially constrained establishments located in economically and financially lagging Western Balkans experienced worse growth performances than those located in the more advanced NMS-10. Second, it studies two different firm growth indicators, namely the widely used growth of sales, as well as the growth of employment to point to and identify potential labor-market consequences of financing constraints that have so far widely been neglected in this line of research (notable exceptions include Hashi (2001) or Aghion, Fally, and Scarpetta (2007)) but are a key concern in the context of jobrich growth. Third, it differentiates between different types of financing constraints to establish whether the effects on growth differ by the relative strictness of prevailing financing constraints. Partly due to data restrictions, this issue has so far not been addressed in the literature. Third, it studies two different economic phases - the pre- and post-crisis periods - to account for the effects of the recent global financial crisis on financing constraints and their role for growth. From a global perspective, the crisis hit the NMS the hardest, particularly the Baltic countries. However, while the severity of the recession was higher in the group of NMS than in the group of Western Balkan countries, recovery was also stronger, leaving fewer legacies in terms of high unemployment rates or excessive nonperforming loans.

The rest of the paper is structured as follows: section 2 provides an overview of the literature on different barriers to firm growth, with a special focus on financial barriers. Section 3 then discusses the data used in the analysis. The prevalence of different financing constraints is briefly discussed in section 4, while section 5 presents the methodological approach applied in the analysis. Results of the analysis are presented and discussed in section 6 , while section 7 summarizes and concludes the paper.

\section{RELATED LITERATURE}

Given the key role of firm growth for employment creation, value-added or knowledge generation, or for research and technology development, this area has been high on the policy agenda of developing and developed countries alike and has sparked substantial research. In general, a quickly burgeoning body of literature finds consistent evidence that firms face numerous non-negligible and partly insurmountable internal and external barriers.

The role of financial systems for growth and the consequences of barriers to finance in terms of retarding or altogether stopping growth has received much attention. Generally, economists tend to hold different views as to the exact role of the financial sector for growth. Some argue that financial systems play a crucial role in stimulating technological innovation and economic development by mobilizing savings, evaluating projects, managing risk, monitoring managers, and facilitating transactions (see Schumpeter 1912), while others highlight that financial development responds to and therefore follows economic development (e.g., Robinson 1952 or Lucas 1988). Empirical evidence seems to corroborate that countries with better developed financial systems also 
experience faster growth (see, e.g., Goldsmith 1969; King and Levine 1993; Levine and Zervos 1998). More recently, thanks to the availability of comprehensive and comparable micro-data, cross-country firm-level analyses have come to support the assertion that 'finance matters,' and that financing constraints are obstructive to growth. For instance, Demirgüç-Kunt and Maksimovic (1998) use firm-level data for 30 developing and developed countries to investigate whether underdeveloped or dysfunctional legal and financial systems prevent firms from investing in growth opportunities. They show that more developed financial systems - proxied by larger banking sectors and more active and liquid stock markets - allow firms to obtain external funds and grow faster than they would if they had to finance growth endeavors internally only or through short-term borrowing. Similarly, prevailing funding obstacles are proven to be detrimental to firm growth. Beck, Demirgüç-Kunt, and Maksimovic (2005) use a rich sample of developing and transition economies, and demonstrate that observable financing obstacles exert a negative effect on firm sales growth. However, the smallest firms are affected the most, which is particularly worrying, since SMEs contribute greatly to the overall economy in terms of job creation, knowledge generation and research and innovation performance. Ayyagari, Demirgüç-Kunt, and Maksimovic (2008) analyze whether, how and to what extent different characteristics of the business environment firms report as obstacles actually affect their sales growth performance. They use the World Bank World Business Environment Surveys for 80 developed and developing economies and show that finance is the most robust and largest obstacle to firm growth. However, effects differ by firm size, leaving smaller firms most affected. Furthermore, among a number of different financing obstacles like collateral requirements, paperwork and bureaucracy, high interest rates, need for special connections, banks lacking money to lend, access to foreign banks, access to nonbank equity, access to export finance, access to financing for leasing equipment, inadequate credit and financial information on customers, or access to long-term loans, only high interest rates are directly and negatively related to firm growth. In particular, a one-standard deviation increase in this particular obstacle leads to a 3.3 percent decrease in firm growth. Similar negative consequences of funding obstacles are observable for establishments located in Central, East and Southeast Europe. Hashi (2001) uses Albanian enterprise survey data and highlights that financial obstacles significantly hamper employment and asset growth of Albanian SMEs. Similarly,
Hashi and Krasniqi (2011) study two different groups of transition economies, namely a group of advanced transition economies (comprising Poland, Hungary and the (zech Republic) and a group of laggard transition economies (comprising Albania, Macedonia and Serbia and Montenegro), to identify differences in growth determinants of SMEs across country groups at different stages of transition. They highlight that external financing constraints only inhibit the growth of sales in the group of advanced transition economies, where, given the advanced stage of economic development, establishments can no longer grow using the owners' own funds only but also need external sources of finance. Furthermore, Rajan and Zingales (1998) use industry-level data for 44 economies over the 1980 s and show that financially dependent industries tend to have better value-added growth performance in more financially developed countries. Similarly, De Serres et al. (2006) test the impact of financial systems' development on sectoral value-added and productivity growth and new firm entry in a rich sample of OECD countries. They highlight that policies that improve contract enforcement, access to credit, the efficiency of bankruptcy procedures, or reduce barriers to entry and government control in the banking sector tend to foster labor productivity and value-added growth in sectors most dependent on external finance. Related to that, Aghion, Fally, and Scarpetta (2007) use harmonized firm-level panel data on entry and post-entry growth of firms in a sample of OECD, transition, and Latin American countries and show that financial development not only spurs new firm entry, but also post-entry employment growth among firms in sectors that more strongly depend on external finance.

In addition to financing obstacles, firm growth is affected by a number of other factors. In particular, specific demographic characteristics of firms are found to inhibit their growth prospects and performance. For instance, small firm size or young age tends to speed up growth. The size-growth nexus is typically analyzed in the context of Gibrat's law, which states that firm size and growth are independent. While empirical evidence is rather mixed and generally leads to a rejection of Gibrat's law, most empirical studies find a negative relationship between firm size and growth. Similarly, empirical evidence more consistently points to a negative relationship between age and firm growth. ${ }^{4}$ However, this relationship seems to be nonlinear, eventually disappearing or even reversing after a certain period of time (see, e.g., Coad and Tamvada 2008; Bigsten and Gebreeyesus 2007). In a similar vein, an establishment's legal form and ownership - as well as changes thereof - matter for 
its growth. For instance, Harhoff, Stahl, and Woywode (1998) highlight that among a sample of West German firms public firms and firms with limited liability have significantly higher growth rates. Furthermore, the growth performance of family-owned businesses, as well as changes in growth due to their transfer to successive generations, have received a fair amount of interest, suggesting that family control exerts a negative impact on firm growth (see, e.g., Gallo, Cappuyns, and Tàpies 2004; Hamelin and Trojman 2007; Mahérault 2004) and that a transfer of familyowned businesses to successive generations tends to result in lower firm growth, at least initially (Molly, Laveren, and Deloof 2010). In addition, a large amount of empirical evidence finds that due to higher levels of efficiency, better knowledge of and access to global markets, and more contacts and networks or better access to financing, foreign ownership is conducive to firm growth (Lipsey, Sjöholm, and Sun 2010; Hake 2009; Bellak 2004; Petkova 2008). Additionally, a series of theoretical papers emphasizes the key role played by innovation for growth (Solow 1957; Aghion and Howitt 1992; Romer 1990; Grossman and Helpman 1991). While the positive effect of innovation on output growth is well documented in the literature, its role for employment has been subject to extensive debate, particularly since product and process innovations both create and destroy jobs, rendering the net effect an a priori unclear outcome. This is also reflected in the vast literature on the employment-effects of innovations, which highlights that the employment effects of process innovations are mixed and inconclusive, ${ }^{5}$ while product innovations are associated with employment growth ${ }^{6}$. Moreover, firm growth also critically depends on establishments' trading activities. Analyses of European firm-level data highlight that exporting exerts a positive effect on firm employment and sales growth (see, e.g., Wagner 2002 or Serti and Tomasi 2008).

Likewise, empirical evidence highlights that individual entrepreneur characteristics also strongly matter for firm growth. In this respect, an entrepreneur's level of education, years of working experience or gender are highlighted in the literature. In particular, as a source of technical, managerial or business knowledge and skills or enhanced learning capacities, (formal) education is expected to spur firm growth. By and large, this positive education-growth nexus is corroborated by empirical evidence (Nichter and Goldmark 2009). Furthermore, theoretically, work experience is expected to be growth-enhancing, since learning-on-the-job is a vital mechanism to enhance the capabilities, knowledge and skills of both owners and employees, therefore contributing to firm growth. However, empirical evidence is rather mixed (particularly for developed countries) (for an overview of the literature, see Nichter and Goldmark 2009) and in some cases even negative (Storey 1994). Furthermore, because of particularly difficult challenges faced by women in terms of asymmetrical rights and obligations or greater problems with innumeracy, illiteracy, and a lack of business skills (Nichter and Goldmark 2009), female-headed establishments tend to grow more slowly (Mead and Liedholm 1998; McPherson 1996; Coad and Tamvada 2008).

Finally, it is widely recognized that the external environment plays a crucial role for firm growth. On the one hand, the state of the economy directly determines profitable business opportunities, rendering economic upturns periods of strong demand, characterized by more favorable growth prospects and generally higher firm growth (Liedholm 2002; Oberhofer 2010). On the other hand, the regulatory and institutional environment shapes and determines business and the growth opportunities of establishments, and may adversely affect an establishment's growth prospects. Previous analyses have demonstrated that labor and product market regulations deter firms from expanding even if successful (Scarpetta et al. 2002; Haltiwanger, Scarpetta, and Schweiger 2006) or that firm growth is significantly lower if firms face financial, legal, and corruption problems (Beck, Demirgüç-Kunt, and Maksimovic 2005), obstacles related to finance, crime or political instability (Ayyagari, Demirgüç-Kunt, and Maksimovic 2008; Hashi and Krasniqi 2011) or consider taxes too constraining (Hashi 2001; Hashi and Krasniqi 2011).

\section{DATA SOURCES}

The ensuing analysis uses firm-level data for a large set of Central Eastern and South Eastern European countries (CESEEC) comprising all new Member States (apart from Malta and Cyprus) (referred to as NMS-10), all of the Western Balkan countries (namely the EU Candidate Countries of the former Yugoslav Republic, including Macedonia (MK), Montenegro (ME), Serbia (RS) as well as Albania (AL), Bosnia and Herzegovina (BA), Croatia (HR) and Kosovo (XK)) and Turkey (TR) to shed light on the role of financing constraints on firm growth in both the pre- and post-crisis periods. It uses the 4th and 5th waves of the Eastern European component of the Business Environment and Enterprise 
Performance Survey (BEEPS), which is a joint initiative of the World Bank Group (WB) and the European Bank for Reconstruction and Development (EBRD). In particular, the 4th wave - which was conducted in the calendar years 2008/09 and refers to fiscal year 2007 is used to analyze the period prior to the onset of the global financial crisis, while the 5th wave - which was conducted between calendar years 2012 and 2013 and refers to fiscal year 2011/12 - is used to shed light on the post-crisis period.

The Enterprise Surveys have been conducted regularly since 2002 by means of face-to-face interviews with managers, owners or directors of establishments on a three- to four-year rotation in order to collect information on the quality of individual firms' business environments, how they are perceived by them and how they change over time, identifying various constraints or obstacles to firm performance and growth and capturing the effects that a country's business environment has on firms' international competitiveness. It focuses on the private, non-agricultural sector of an economy.

Country samples are selected using random sampling, stratified by firm size (small: 5-19 employees; medium: 20-99 employees; large: more than $99 \mathrm{em}-$ ployees), region (of major economic activity) and industry (based on the ISIC classification, revision 3.1, covering all manufacturing sectors (group D), construction (group F), services (groups $\mathrm{G}$ and $\mathrm{H}$ ), transport, storage and communications (group I) and IT (from group K)). The primary sampling unit of each survey is the establishment with five or more full-time employees, located in a major urban center, and engaged in non-agricultural activities. This particular sampling methodology generates country samples that are representative of the whole non-agricultural private sector. Available sampling weights which account for the varying probabilities of selection across different strata can be used to derive population estimates. Furthermore, the standardized sampling strategy and survey instruments used in collecting the data guarantee that survey data from different countries are comparable.

Country samples are also adjusted to account for items that elicit non-responses - questions with missing responses - which is a problem the Enterprise Survey shares with other surveys, since some data, particularly accounting data, are considered too sensitive to share. Item non-responses are accounted for by factoring in a rate of 25 percent for non-responses per stratum. This automatically increases the number of necessary interviews, but guarantees that enough valid responses are available to compute indicators with the required precision.

Overall, the pre-crisis sample consists of 6,182 establishments, while the post-crisis sample covers 6,009 establishments (see Table A.1 in the Annex for a more detailed overview by country and period and Table A.2 for summary statistics).

\section{THE PREVALENCE OF DIFFERENT FINANCING CONSTRAINTS}

The analysis uses two different proxy variables for financing constraints to identify whether and to what extent such constraints affect firm growth. First, the dummy variable Rejected is derived from the following question covered in the BEEPS questionnaire: 'Referring to this most recent application for a line of credit or loan, what was the outcome of that application?' Several options are available to the interviewee: a) the application was approved, b) the application was rejected, c) the application was withdrawn by the establishment, d) the application is still in process, and e) don't know. The dummy variable Rejected is set equal to 1 if the application was rejected, and 0 if the application was either withdrawn by the establishment or was still in process at the time of the interview, while "don't know" is treated as missing. Second, the dummy variable Constrained is derived from the following question in the BEEPS questionnaire: 'What was the main reason why this establishment did not apply for any line of credit or loan?' A number of different options were available to the interviewee. The variable Constrained is set equal to 1 for either of the following reasons: (i) the application procedures were complex, (ii) interest rates were not favorable, (iii) the collateral requirements were too high, (iv) the size of the loan and maturity were insufficient, $(v)$ it was necessary to make informal payments to get bank loans, (vi) did not think it was approved, and finally, (vii) other (not specified). It is equal to 0 if there was no need for a loan, since the establishment had a sufficient amount of its own capital. The first indicator (i.e. Rejected) will be used to analyze the sub-set of establishments which actually applied for any loans or lines of credit, while the second indicator (i.e. Constrained) will be used for the sub-set of establishments which - for all of the different reasons outlined above - did not apply for any loans or lines of credit, despite the need for funds. 
Figure 1: Prevalence of different types of constraints

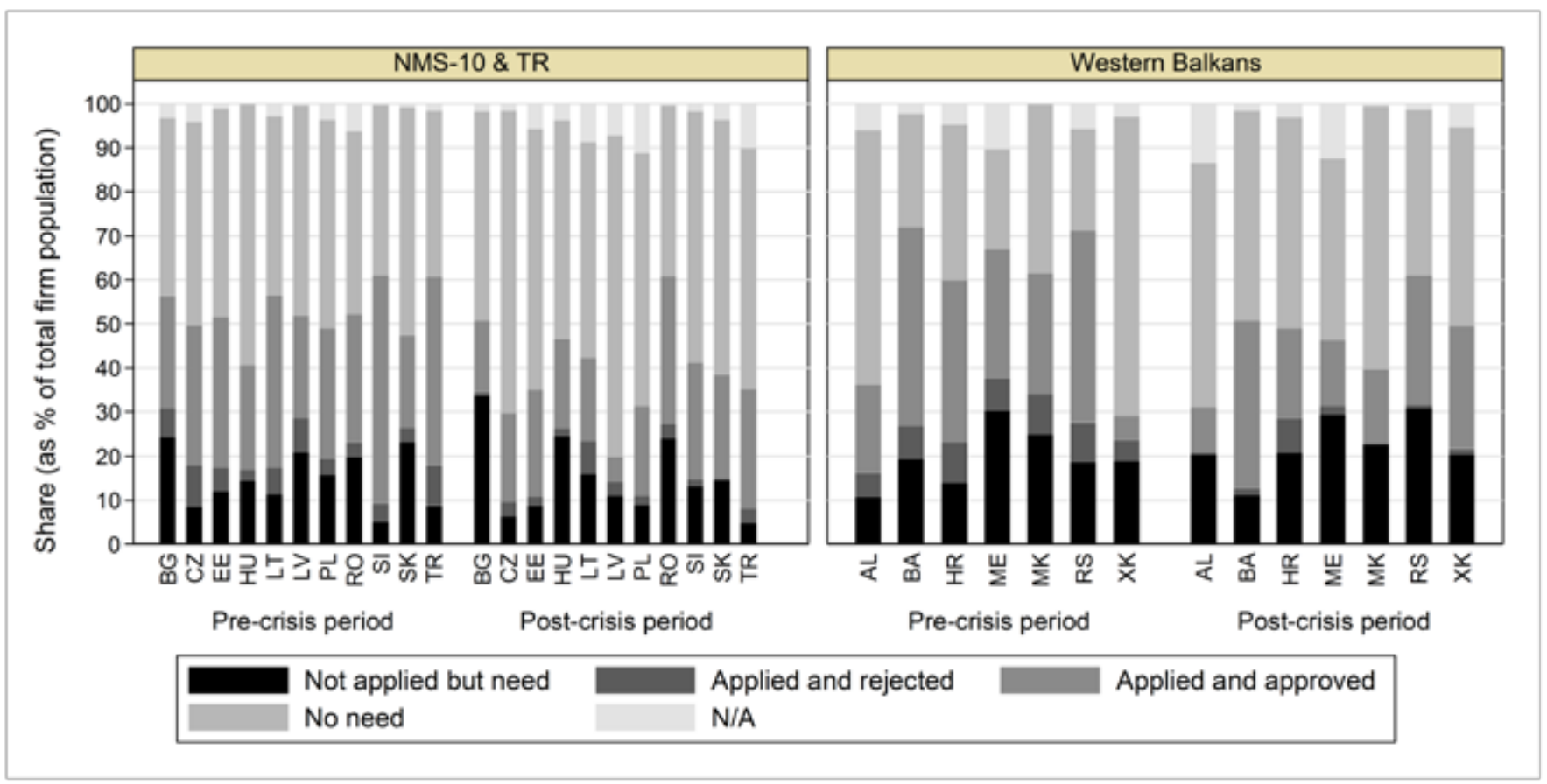

Note: NMS-10 comprises Bulgaria (BG), the Czech Republic (CZ), Estonia (EE), Hungary (HU), Latvia (LV), Lithuania (LT), Poland $(\mathrm{PL})$, Romania (RO), Slovakia (SK), and Slovenia (SI). TR refers to Turkey. The Western Balkans comprise Albania (AL), Bosnia and Herzegovina (BA), Croatia (HR), Montenegro (ME), the former Yugoslav Republic of Macedonia (MK), Serbia (RS) and Kosovo (XK).

Source: BEEPs, own calculations.

The prevalence of different types of financing constraints is depicted in Figure 1 for each country and period separately. It points to a number of interesting findings: first, irrespective of country or economic period considered, credit constraints (labeled 'Applied and rejected') were only of little importance, while constraints of establishments that would have needed external funds but restrained from applying for bank loans (labeled 'Not applied but need') dominated. Interestingly, with the exception of Lithuania, credit constraints were more widespread during the precrisis period, which is probably the result of more and riskier credit applications during the pre-crisis credit boom. Second, the extent of financing constraints varies across countries. During the pre-crisis period, among NMS-10 countries, financing constraints were lowest in Slovenia (with around 10 percent) but highest in Bulgaria (with around 30 percent), followed by Latvia and Slovakia. During the post-crisis period, financing constraints in Bulgaria increased even further, to almost 35 percent. On the contrary, financing constraints were lowest in Turkey, the Czech Republic, Estonia and Poland. In the Western Balkan countries, financing constraints during the pre-crisis period were lowest in Albania with around 15 percent, and highest in Montenegro and Macedonia, with above 30 percent. During the post-crisis period, financing constraints decreased significantly in Macedonia, Bosnia and Herzegovina and Montenegro, while they increased somewhat in Albania and Serbia. Third, the majority of establishments had their bank loan applications approved, rendering a rejection a rather rare incident.

\section{DRIVERS OF AND OBSTACLES TO FIRM GROWTH: METHODOLOGICAL APPROACH}

To shed light on the role of prevailing financing constraints for firm growth and on whether their growth-effects differ across country samples, the following specification is analyzed ${ }^{7}$ :

$$
\begin{gathered}
\text { Growth }_{i j k t}=\alpha+\beta_{1} F C_{i j k t}^{m}+\beta_{2} \text { Balkan }_{k t}+\beta_{3} F C_{i j k t}^{m} * \text { Balkan }_{k t}+\gamma X_{i j k t}+\cdots \\
\ldots \delta Y_{j t}+\vartheta D_{k t}+\varepsilon_{i j k t}
\end{gathered}
$$


where Growth $_{i j k t}$ is the dependent variable and refers to the annualized growth rate (between time $t$ and $t-3$ ) of establishment $i$ in industry $j$ and country $k$ at time $t .{ }^{8}$ As highlighted above, the analysis uses two different growth indicators, namely (i) growth in sales and (ii) growth in (full-time, permanent) employment. Furthermore, the analysis sheds light on the effects of the global financial crisis on the determinants of establishment growth. Unfortunately, even though during the data gathering procedure maximum effort was taken to generate country panels by re-interviewing establishments, the panel structure of the underlying country sample is rather poor. This renders the use of panel data analyses which account for unobserved establishment heterogeneity futile. Hence, instead, the analysis looks at two different periods separately: the pre-crisis period, referring to fiscal year 2007 (t $=2007)$, and the post-crisis period, referring to fiscal year 2011/12 $(t=2011 / 12)$.

$F C_{i j k t}^{m}$ is the main variable of interest, capturing the effect of different types of financing constraints on firm growth ( $m=$ Total, Rejected or Constrained). As highlighted in section 4, the analysis differentiates between two different types of financing constraints, namely Rejected, which is equal to 1 for establishments that applied for a bank loan but whose credit application was rejected (and 0 otherwise), and Constrained, which is equal to 1 for establishments that would have needed external funds, but due to different reasons (outlined above) did not apply for loans or lines of credits (and 0 otherwise). As a starting point, a composite financing constraint variable is used, namely Total. It is a dummy variable that is equal to 1 for establishments that faced any kind of financing constraints, i.e. Rejected or Constrained, and 0 otherwise. This allows us to shed light on the determinants of growth, in general, and the role of financing constraints, in particular, for all firms in the sample. In contrast, differentiating between the two different types of financing constraints separates the overall firm sample in two separate sub-samples - depending on whether establishments faced one or the other type of financing constraint - potentially leading to different inferences depending on the average characteristics of all establishments in the two different samples.

Balkan $_{k t}$ is a dummy variable that is equal to 1 if a country is a Western Balkan country, and 0 otherwise. It is included to test whether establishments located in the Western Balkans grow at significantly different rates than those located in the more advanced NMS10 countries.
$F C_{i j k t}^{m} *$ Balkan $_{k t}$ is an interaction term between two dummy variables, namely between each individual type of financing constraints $F C_{i j k t}^{m}$ and Balkan $_{k t}$. It is included to capture whether (different types of) financing constraints exert different effects on the growth of establishments located in Western Balkan countries compared to those located in the NMS-10 region.

Furthermore, $X_{i j k t}$ is a matrix of establishment-level control variables, capturing:

Firm age: defined as the log of firm age, calculated as the difference between the current year $t$ and the year of the firm's establishment or registration. It is included to test for the empirically supported assertion that age and growth are negatively related. Furthermore, to test for the presence of a non-linear relationship between firm growth and age, the square of log firm age is also included.

Firm size: defined as the firm's initial size and included to test the size-growth nexus. As highlighted above, most empirical studies find a negative relationship between firm size and growth. Contingent on the particular dependent variable studied, different measures of firm size were used to avoid issues of endogeneity. In particular, for the sales growth equation, the log of the initial number of employees was used, while for the employment growth equation, the log of initial sales was used instead. In addition, to test for the presence of a non-linear relationship between firm growth and size, its square terms were also included.

Years of experience of Top Manager: defined as the log of the number of years of work experience of the Top Manger in the establishment's sector. It captures whether the Top Manager's work experience is indeed growth-enhancing. In general, however, empirical evidence is rather mixed and sometimes even negative.

Ownership structure: the analysis uses two different ownership indicators to test whether a particular ownership structure is more conducive to growth: first, the share of the establishment owned by private foreign individuals, companies or organizations (in \%); second, the share of the establishment owned by the government or state (in \%); the share of the establishment owned by private domestic individuals, companies or organizations serves as a reference group. Empirical evidence generally emphasizes that foreign ownership is conducive to firm growth.

Trading status: captured by means of three different dummy variables. First, a dummy variable is included for exporters only, which is equal to 1 if an establishment is a direct exporter only (i.e. reports positive direct exports only but no direct imports of material inputs or supplies), and 0 otherwise. Second, 
a dummy variable is included for importers only, which is equal to 1 if an establishments is a direct importer of material inputs or supplies only (but no direct exporter), and 0 otherwise. Finally, a dummy variable is included for exporters and importers, which is equal to 1 if an establishment is both a direct exporter and a direct importer, and 0 otherwise. Trading status is included to identify whether exporters, through more diversified markets and customer bases or better technological capacities and improved competitiveness, grow faster or whether importers, through better access to foreign knowledge and technology, grow faster.

Product innovator: a dummy that is equal to 1 if an establishment introduced a new or significantly improved product or service during the previous three years. Unfortunately, given the absence of information on process innovations in the $4^{\text {th }}$ wave of the Enterprise Survey, their role for firm growth could not be consistently estimated. Empirically, product innovations are generally found to be associated with stronger employment growth.

Big city: a dummy that is equal to 1 if an establishment is located in the capital city or a city with a population of over $1 \mathrm{M}$. It is included to highlight that establishments located in larger cities/metropolises profit more from growth-enhancing spillovers than those located in less densely populated areas.

$Y_{j t}$ refers to a matrix of country characteristics:

Real GDP growth rate: defined as the average annual real GDP growth rate (in \%) (over the last three years) to capture the state of the economy and the potentially favorable growth opportunities it offers to establishments.

Institutional characteristics: a number of different institutional characteristics to test whether and how the institutional environment affects the business and growth opportunities of establishments. First, paying taxes, which refers to all taxes and contributions that are government mandated (at any level: federal, state or local) and that apply to the standardized business and have an impact in its financial statements; second, starting a business which refers to all procedures officially required, or commonly done in practice, for an entrepreneur to start up and formally operate an industrial or commercial business, as well as the time and cost to complete these procedures and the paid-in minimum capital requirement; third, resolving insolvency, which refers to the time, cost and outcome of insolvency proceedings involving domestic entities. These indicators stem from the WB 'Distance to Frontier' Database. The reported score benchmarks economies with respect to regulatory best practices, showing the absolute distance to the best performance on each indicator. An economy's distance to frontier is indicated on a scale from 0 to 100 , where 0 represents the worst performance and 100 the frontier. Hence, in any given year, the score measures how far an economy is from the best performance at that time.

Finally, $D_{k}$ refers to industry dummies (i.e. Manufacturing, Construction with Services as reference group), while $\varepsilon_{i j k t}$ refers to the error term.

However, the above specification may result in badly estimated coefficients because of the endogeneity of the product innovation indicator. In particular, faster growing firms may have a larger incentive to introduce new product innovations, which in turn fosters further growth. Hence, to deal with endogeneity, a 2SLS approach is pursued in what follows, which solves a two-equation system and produces efficient estimators. Potential instruments for the endogenous variable must be related to whether product innovations were introduced but were unrelated to the error term. Several candidates were taken into account, but based on different tests, the analysis uses (all or some of) the following exogenous instruments:

Innovation strategy: three different innovation strategies are deemed relevant for the success of an establishment's innovative activities. In particular, as highlighted by Veugelers and Cassiman (1999), establishments often apply different innovation strategies to develop technological innovations: establishments either (i) invest in R\&D to 'make' innovations in-house or indigenously, (ii) source externally and invest in machinery and equipment (M\&E) and 'buy' technology and know-how embodied in machinery and equipment from the original innovator that can then be used to also develop new products or services or modify existing ones, or (iii) apply a mix of both strategies, both making and buying innovations and technology. Hence, three dummy variables are used: make only for establishments that only pursue the make-strategy, identified by current positive R\&D expenditures, buy only for establishments that only pursue the buystrategy, identified by positive investments in machinery and equipment or the use of technology licensed from a foreign-owned company, and make and buy for establishments that pursue both strategies. The three dummy variables are equal to 1 if the respective innovation strategy is pursued, and 0 otherwise.

ISO: a dummy variable that is equal to 1 if the establishment has an internationally-recognized quality certification.

Computer use: a dummy variable that is equal to 1 if an establishment's workforce currently uses computers in their jobs, and 0 otherwise.

A number of test statistics were used to determine the validity of the abovementioned instruments. 
Serious problems arise if the correlations between the excluded instruments and endogenous regressor are nonzero but only 'weak', such that the excluded instruments have little explanatory power only, i.e. if the correlations between the endogenous regressor and the excluded instruments are nonzero but small. Hence, the Stock-Yogo (2005) test for the presence of weak instruments is used, which tests the null hypothesis that the estimator is weakly identified only and is therefore subject to bias one finds unacceptably large. The test for weak identification is an F-version of the Cragg-Donald Wald statistic. Stock and Yogo (2005) have compiled critical values for the CraggDonald F-statistic for different definitions of 'perform poorly' based on bias and size. Hence the Stock-Yogo weak-instruments test comes in two forms: maximal relative bias and maximal size, where the null is that the instruments do not suffer from the specified bias. Rejection of their null hypothesis represents the absence of a weak-instruments problem. To test whether (1) is identified, the Anderson (1984) underidentification test is used, which uses canonical correlations between the excluded instruments and the endogenous regressors. Anderson's likelihood ratio test tests the null hypothesis that the smallest canonical correlation is zero. A failure to reject the null hypothesis calls the identification status of the estimated equation into question. Furthermore, an overidentification test of all instruments is conducted based on the Sargan statistic. Rejection of the null hypothesis highlights that the instruments used in the analysis are not valid. Finally, an endogeneity test is conducted, which tests the null hypothesis that the specified endogenous regressor can actually be treated as exogenous. Rejection of the null hypothesis means that the variable needs to be treated as endogenous.

\section{FINDINGS}

The results in Tables 1 and 2 highlight that financing constraints (FC) do significantly obstruct firm growth, in terms of both sales and employment. The exact effects, however, differ by the type of financing constraint and the economic period considered. In particular, the composite financing constraint indicator (FCTotal) is significantly negative, irrespective of period considered. This finding suggests that, in the pre-crisis period, financially constrained establishments had almost 8 percentage points lower sales growth rates and 4 percentage points lower employment growth rates than unconstrained establishments, while in the post-crisis period financially constrained establishments had only around 6 percentage points lower sales growth rates and 4 percentage points lower employment sales growth rates than unconstrained ones. The results are less robust once the two different types of financing constraints are considered instead. In particular, irrespective of period considered, establishments whose credit applications were rejected (FC-Rejected) did not experience significantly lower sales growth rates, but around 6 percentage points lower employment growth rates than unconstrained establishments. However, this only holds for the postcrisis period. On the contrary, growth effects are more obstructive for establishments that abstained from applying for bank loans despite the need for external financing (FC-Constrained). During the post-crisis period only, establishments in need of external funds experienced around 6 percentage points lower sales growth rates than those that had no need for external funding. However, irrespective of period considered, establishments with a need for external funding had around 4 percentage points lower employment growth rates than those that had no such need.

Our results also show that sales and employment growth experiences differed across country samples. During the post-crisis period, employment growth rates were between 2 and 3 percentage points higher in the Western Balkans than in the group of NMS-10 (plus Turkey) $)^{9}$. In contrast, sales growth rates did not differ significantly across the two country groups.

Furthermore, we also find geographically differentiated growth-effects of financing constraints, but only in terms of employment growth and only during the pre-crisis period. With an average of around 7 percentage points lower employment growth rate, financing constraints were significantly more harmful to the employment growth of establishments located in the economically less advanced Western Balkan countries than to those located in the group of economically more advanced NMS-10 countries (plus Turkey).

In line with related empirical evidence, we find a significant negative relationship between firm age and growth. Our results suggest that another year of an establishment's life is associated with around 0.5 percentage points lower sales growth rate and around 0.1 percentage points lower employment growth rate. However, the relationship between age and employment growth (in the post-crisis period only) is characterized by a non-linear, U-shaped relationship, highlighting that the negative age-growth effect eventually dies out and probably even reverses as establishments grow older.

Similarly, in line with related empirical results, there is also consistent evidence of a significant negative size-growth nexus and a non-linear, U-shaped relationship between size and growth. However, for sales growth, this U-shaped relationship is confined to the 


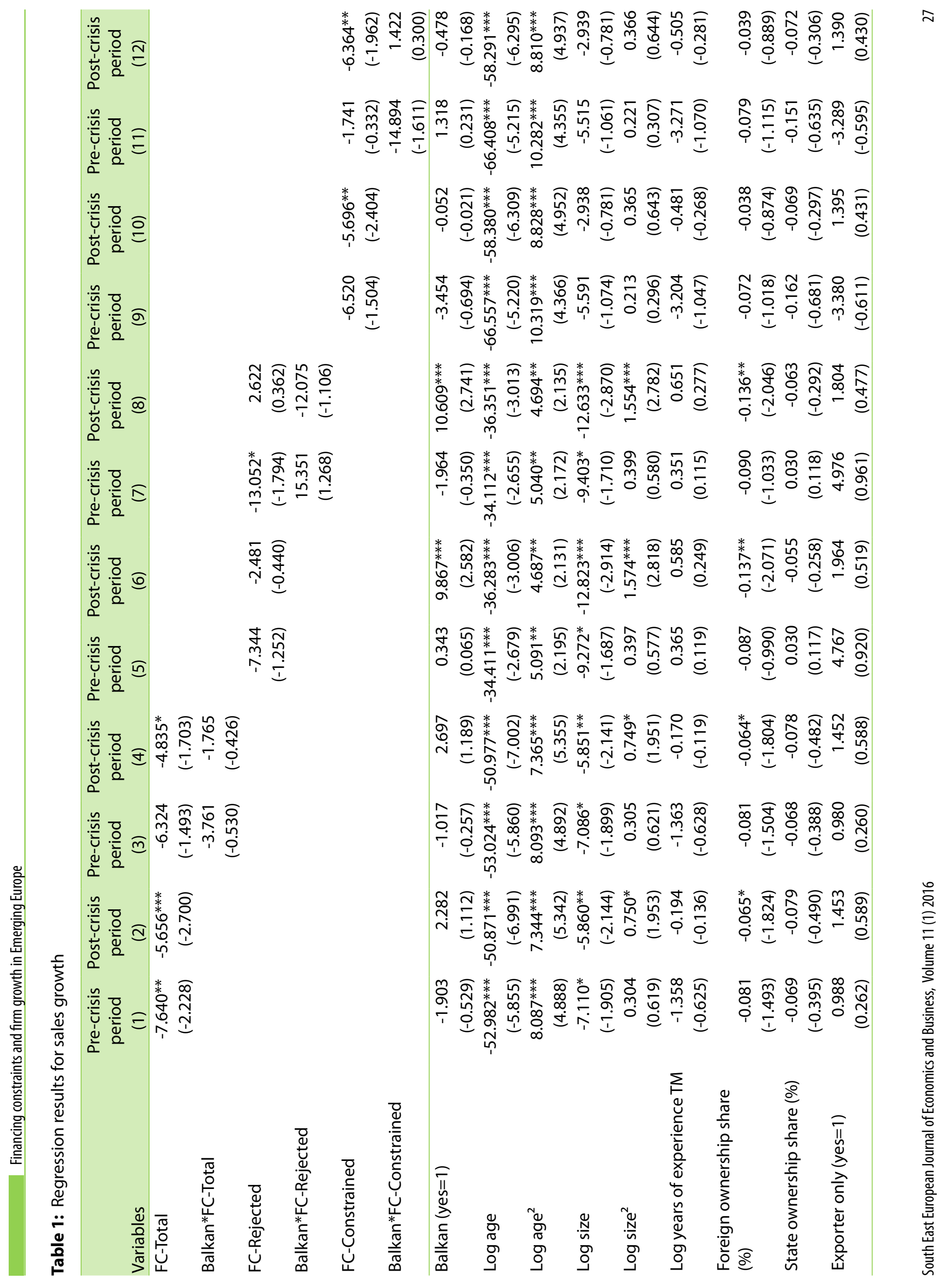




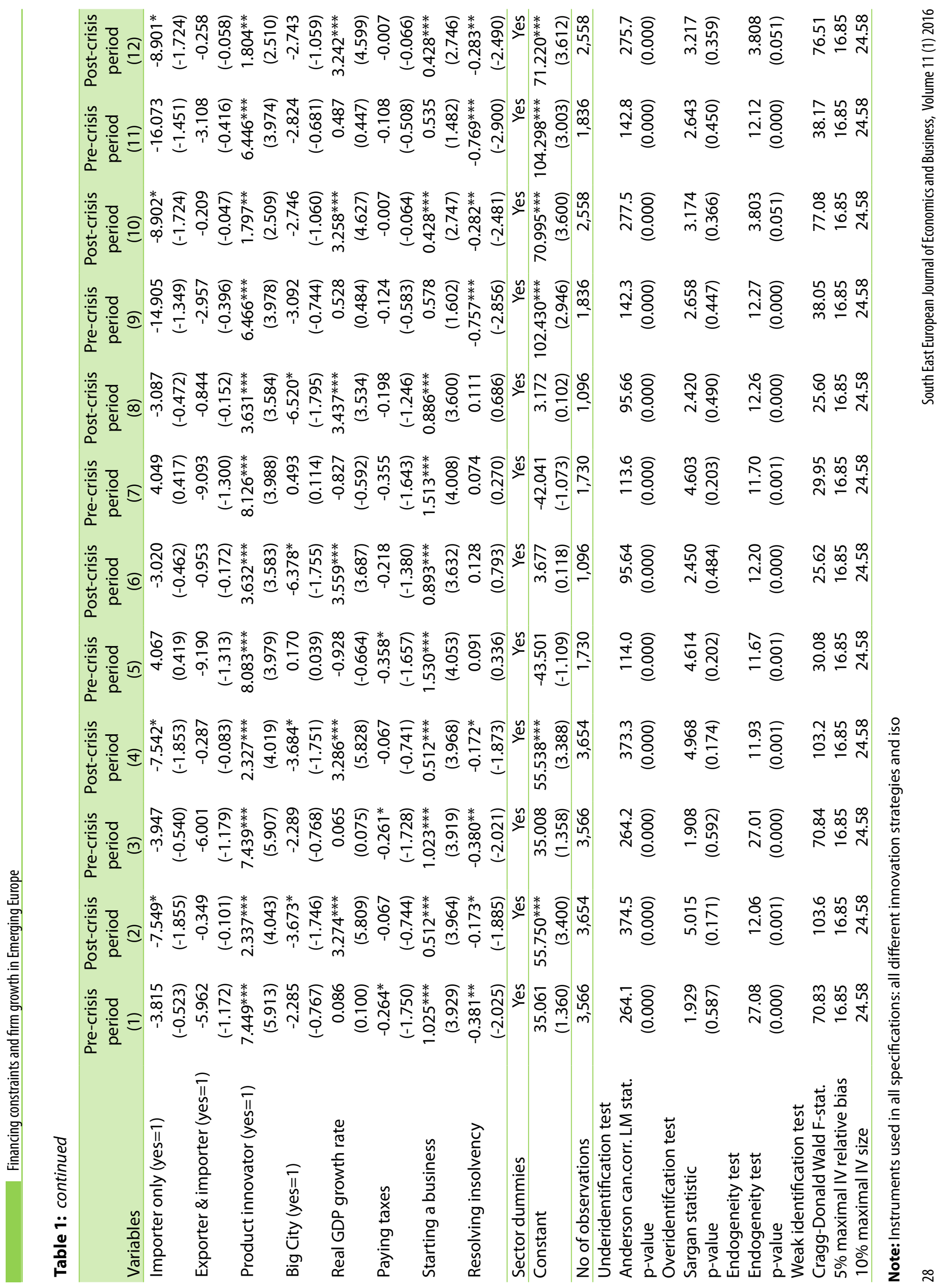


post-crisis period only, while for employment growth it refers to the pre-crisis period only.

Counter to expectations, the Top Manager's work experience in the industry plays a rather limited role. While the Top Manager's work experience is irrelevant for an establishment's sales growth, it exerts a significant negative effect on an establishment's employment growth. However, this negative effect only emerges during the post-crisis period and seems to suggest that more experienced Top Managers pursued more conservative and cautious employment policies in a business environment still characterized by strong crisis-related domestic and global uncertainties.

In a similar vein, ownership structure matters little for firm growth. In contrast to related empirical evidence, we find that foreign ownership is associated with both significantly lower sales and employment growth, though at different points in time: in the pre-crisis period, a higher foreign ownership share (by another percentage point) was associated with (0.03 percentage points) lower employment growth, while in the post-crisis period it was related to $(0.06$ percentage points) lower sales growth. In contrast, higher state-ownership exerted no significant effect on either sales or employment growth.

Furthermore, an establishment's particular trading status matters for its sales growth experience, with effects again differing by period. In the pre-crisis period, when global demand was high and trade flourished, exporters only experienced significantly higher employment growth rates than establishments that sourced from and catered to domestic markets only. However, in the post-crisis period, which was still characterized by muted global growth and only slowly recovering global trade, importing establishments experienced significantly lower sales growth than establishments that sourced from and catered to domestic markets only. Hence, before the financial crisis struck, exporting to international markets proved conducive to employment growth. This advantage and associated growth stimulus from exporting disappeared as a result of the crisis. In the aftermath of the crisis, importing turned out to be obstructive to sales growth.

An important finding of our analysis is the consistent positive growth-effect of innovation. As expected, it makes a huge difference for both sales and employment growth whether an establishment is a product innovator or not. 10 Irrespective of the period considered, product innovators - i.e. establishments that introduced a new product or service - grew significantly faster than non-product innovators. The growth-effect was markedly stronger in the pre-crisis period, yet, due to sluggish and only slowly recovering domestic and global demand, it fell considerably in the post-crisis period. Hence, innovativeness turns out to be a recipe for success, guaranteeing more pronounced growth, even during economically difficult times.

Our results also point to 'agglomeration' effects and the importance for growth of being located in more densely populated, more competitive environments. More specifically, we find evidence of temporary diseconomies of agglomeration. Probably due to lower demand and fiercer competition in the wake of the global financial crisis, establishments located in larger cities experienced both significantly lower sales and employment growth rates. A more nuanced picture emerges, however, for the sub-sample of firms that applied for bank loans. For this particular sample of establishments, both economies as well as diseconomies of agglomeration are present, although at different points in time: during the pre-crisis period, being located in a larger city proved conducive to employment growth, while during the post-crisis period the opposite effect was present, rendering larger cities less advantageous and growth-restricting locations for establishments.

We also tested the relevance of a set of macroeconomic characteristics for firm growth. First, in line with related empirical evidence, our results indicate that the state of the economy, which determines an establishment's growth opportunities, is conducive to its sales and employment growth. Second, the institutional environment turns out to matter greatly, which points to the important role policy-makers play for creating a business environment that is attractive and conducive to growth. However, the exact direction and scale of the growth-effect differ depending on the particular institution considered. In particular, business environments that make starting a business a comparatively easy and cheap endeavor are very conducive to sales growth, and were particularly conducive to sales growth in the pre-crisis period. However, no significant role is observable for employment growth, which suggests that newly entering establishments are very small in size, producing no or only limited demand for additional labor. On the contrary, business environments that help resolve insolvencies in a quick and costless manner are obstructive to sales growth, resulting in significantly lower sales growth, particularly in the pre-crisis period, and significantly lower employment growth since, as a consequence, the firing of personnel becomes an administratively and legally easy and costless effort. Business environments with conducive tax regimes in terms of tax rates, the number of number of times the establishment pays taxes or the time taken to prepare, file and pay taxes (i.e. high distance-to-frontier rankings) are obstructive to sales growth but conducive to employment growth, particularly during the pre-crisis period. 


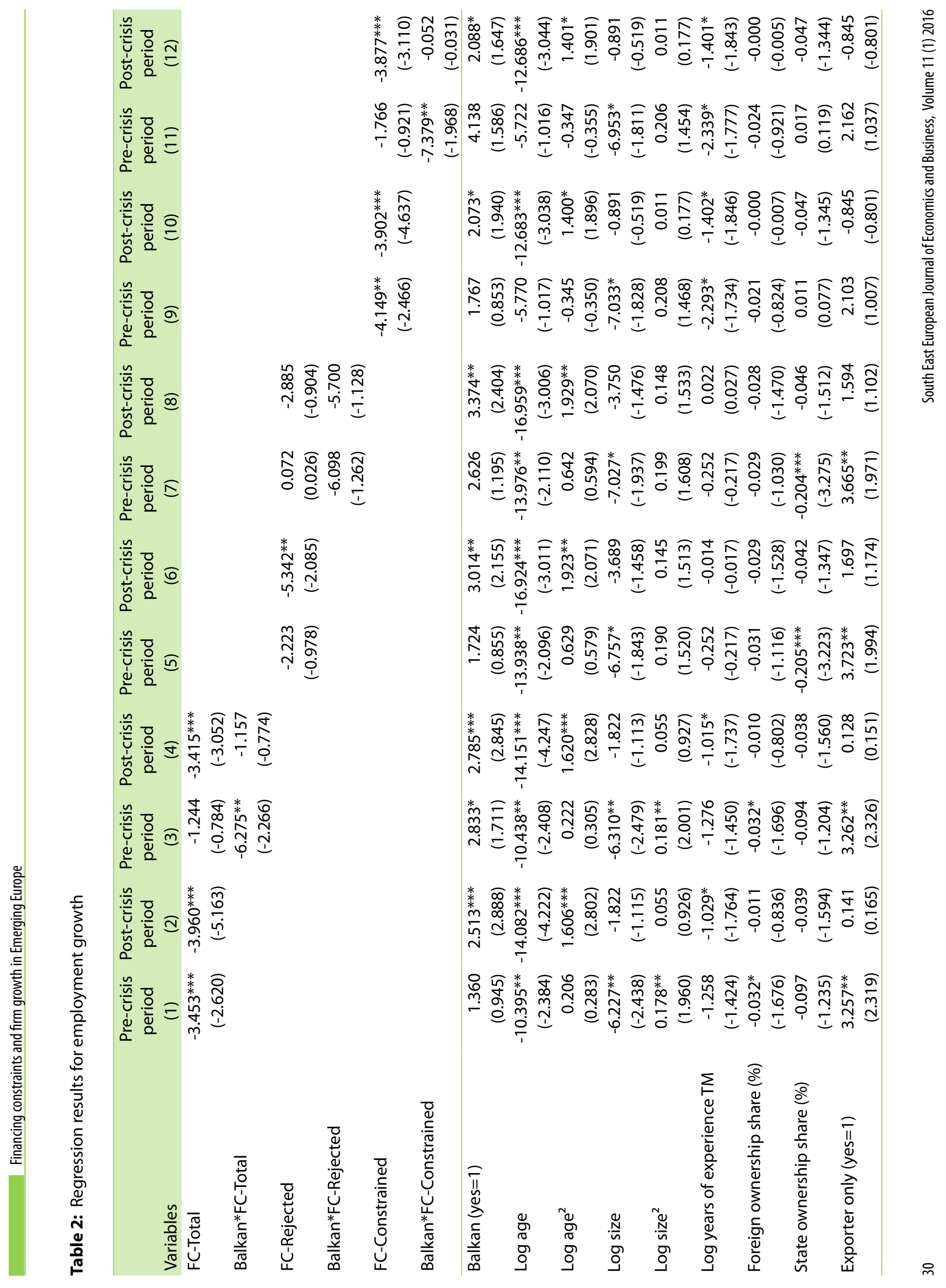




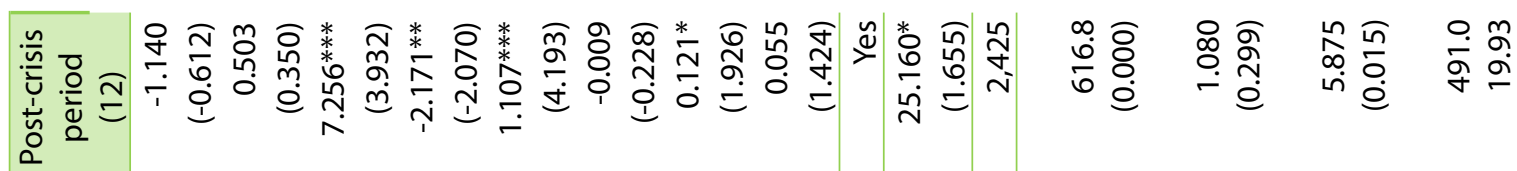

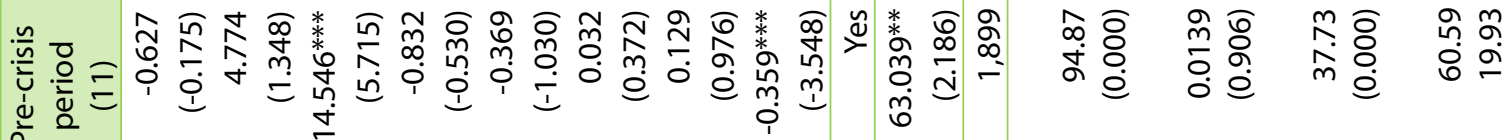

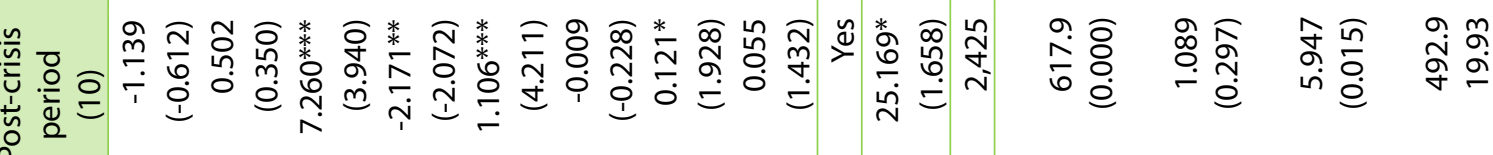

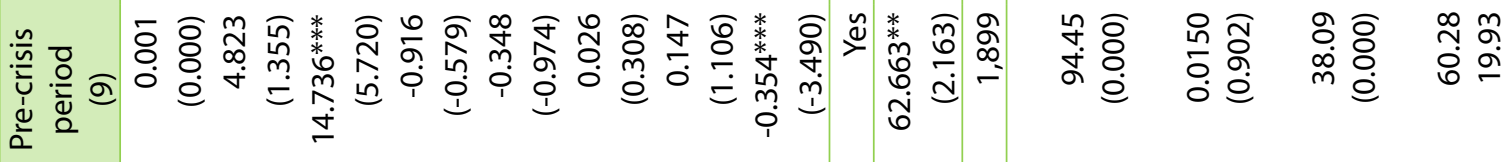

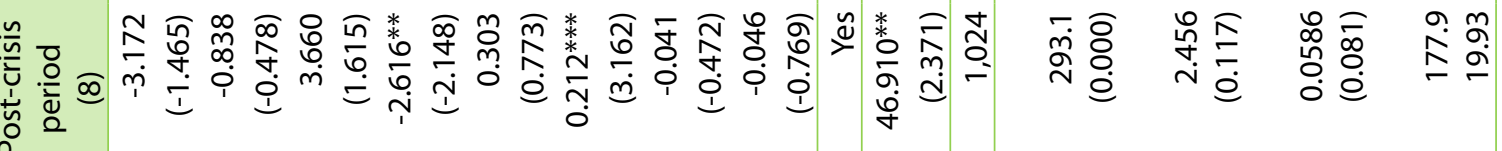

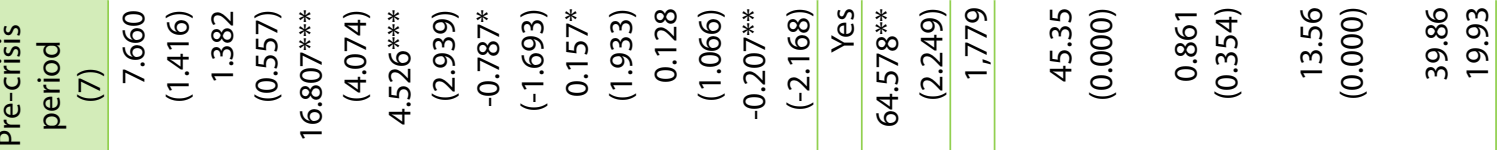

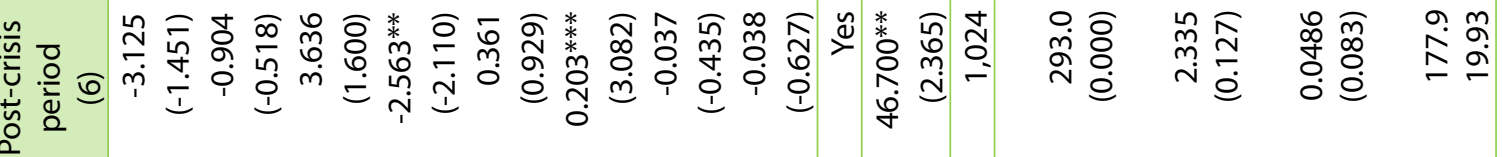

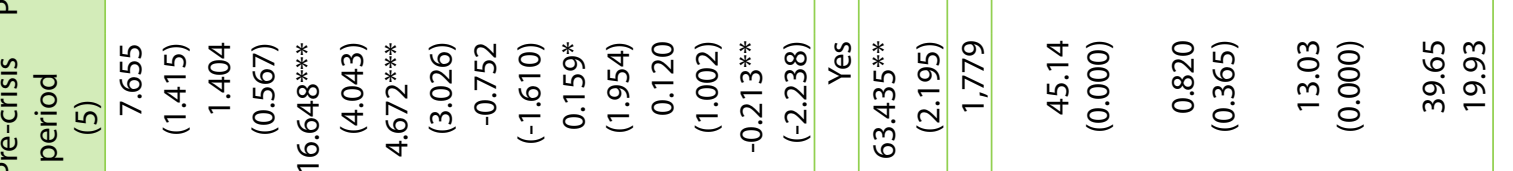

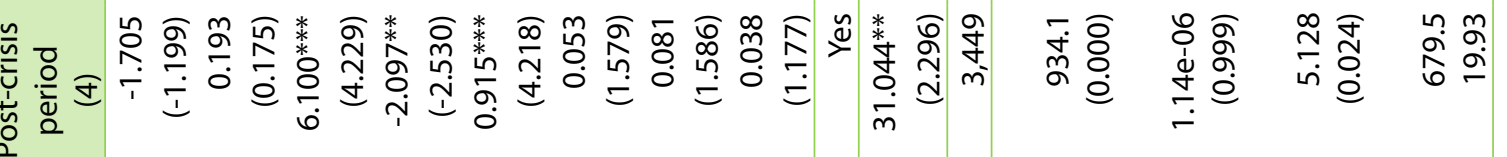
帝家

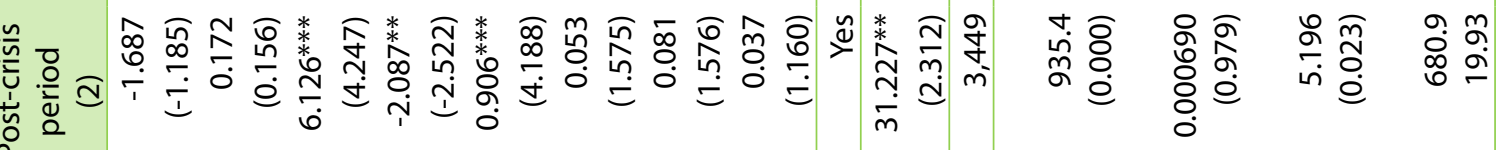

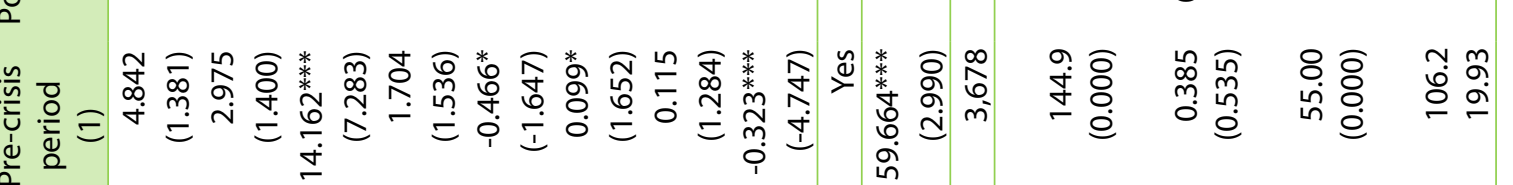




\section{SUMMARY AND CONCLUSION}

A quickly growing body of empirical literature finds robust evidence that establishments face non-negligible financial constraints that prove detrimental to their performance and growth. These impediments to external funding are particularly worrying in economically lagging economies, where easy and unhindered access to financial markets is not only a crucial factor for the growth and survival of establishments, but, more imporatantly, for economic growth and catching-up processes with richer economies.

Against this backdrop, the analysis uses firm-level data for a large set of European emerging economies to identify the effects of financing constraints on firm growth. It analyzes and compares the economically more advanced group of NMS-10 (plus Turkey) and the group of economically and financially lagging Western Balkan countries and tests whether the growth-effects of financial constraints differ by the stage of transition in each economy. Furthermore, it addresses some gaps in the literature (i) by looking at growth in terms of sales and employment to also address the grossly under-researched labor market effects of financing constraints; (ii) by differentiating between different types of financing constraints to demonstrate how growth-effects differ by the strictness of financing constraints; and (iii) by studying the effects of the global financial crisis on the constraint-growth nexus.

In line with related empirical evidence, our results highlight that financing constraints significantly obstruct firm growth, although the exact effects differ by growth indicator, the type of financing constraints present and the economic period. In general, observable negative effects are most robust for employment growth and suggest that establishments whose credit applications were rejected experienced lower employment growth than those that, despite the need for external funding, did not apply for a bank loan for reasons pertaining to complex application procedures, unfavorable interest rates, high collateral requirements, insufficient size and maturity of loans or the necessity to make informal payments to get the loan. Furthermore, the results point to geographic differences in the growth-effects of financing constraints and highlight that only during the pre-crisis period were financial constraints more harmful to employment growth in establishments located in the economically less advanced Western Balkans than to establishments located in the group of economically more advanced NMS-10 (plus Turkey). Together, these results emphasize the need for policy intervention in Emerging Europe to reduce existing financing constraints, subject to compliance with financial prudence, to ensure swifter job-rich growth and stimulate catching-up with richer economies. However, the need for action is much stronger in the Western Balkans, where financing constraints also prove significantly more damaging to growth.

In addition, the analysis identifies particular firm characteristics and institutions that matter for firm growth and therefore call for management action and policy intervention. For instance, it consistently shows that exporters only grow faster - in terms of employment - than domestically-oriented establishments, and that, in general, product innovators grow faster than non-innovators. This suggests that entrepreneurs should more strongly engage in exporting, and perhaps more importantly, in innovating for stronger establishment growth and policy-makers need to devise and implement policies and measures that encourage and facilitate activities such as export promotion schemes to inform and train exporters and to guarantee and help fund exports or innovation policies that help improve the performance of research and innovation systems. By contrast, our findings highlight that being an importer only was harmful for sales growth only during the post-crisis period, when global trade and growth were still weak, or when the Top Manager's higher work experience was disadvantageous for employment growth. This latter effect was particularly relevant for the post-crisis period and suggests that more experienced Top Managers probably resort to more conservative and cautious hiring policies during economically turbulent and uncertain times. Moreover, contrary to related empirical evidence, foreign ownership, which is expected to boost growth through easier access to knowledge and superior technology, global markets, contacts and networks, turns out to be an impediment to faster sales and employment growth, although at different points in time. The presence of a negative growtheffect seems to suggest that foreign-owned establishments in Emerging Europe are unable to reap the benefits of foreign-ownership, which emphasizes the need for appropriate management action to identify and eliminate internal bottlenecks and problem areas. Furthermore, it corroborates the negative size-growth and age-growth hypotheses identified in the literature and highlights that old age or large size are disadvantageous for both sales and employment growth. However, these negative effects of size and age tend to diminish as establishments grow larger and older, and eventually even reverse.

Finally, the analysis shows that the state of the economy and the institutional environment matter for establishment growth, a finding that is highly relevant for policy makers in Emerging Europe, who 
need to build a business environment conducive to growth and develop and implement policies aimed at encouraging (job-rich) growth and fostering swifter catching-up with richer economies. For instance, business environments with favorable tax regimes were conducive to employment growth but obstructive to sales growth - particularly before the global financial crisis hit Central East and Southeastern Europe. Furthermore, business environments that make starting a business a comparatively easy and cheap endeavor were conducive to sales growth - particularly in the pre-crisis period - but had no significant effect on employment growth whatsoever. Hence, a business environment that is conducive to starting a business does not automatically guarantee job-rich growth. And business environments that help resolve insolvencies in a quick and costless manner were obstructive to both sales and employment growth, since liquidating an establishment and firing its personnel is guaranteed to be an administratively and legally easy and comparatively costless effort.

\section{ENDNOTES}

1 In particular, financially constrained establishments are found to have significantly lower R\&D investment levels (Triwari et al. 2007; Mancusi and Vezzulli 2010). Furthermore, financially constrained establishments are significantly less likely to penetrate new markets and export (Minetti and Zhu 2011), to pursue R\&D activities (Mancusi and Vezzulli 2010; Mohnen et al. 2008; Männasoo and Meriküll 2011; Hajivassilou and Savignac 2008 or Álvarez and Crespi 2011) to invest in capital goods (Hasan 2013) or to offer formal training programs to their employees (Popov 2013), to name but a few of their negative consequences.

2 The group of NSM-10 countries comprises Bulgaria, the Czech Republic, Estonia, Hungary, Latvia, Lithuania, Poland, Romania, Slovakia and Slovenia.

3 The group of Western Balkan countries comprises Albania, Bosnia and Herzegovina, Croatia, Kosovo, the former Yugoslav Republic of Macedonia, Montenegro and Serbia.

4 See, e.g., Dunne et al. (1989), Evans (1987a, b), Variyam and Kraybill (1992), Sleuwaegen and Goedhuys (2002), Geroski and Gugler (2004) or Dollar, Hallward-Driemeier, and Mengistae (2005).

5 Specifically, positive effects are found by Smolny (1998), Lachenmaier and Rottmann (2006) and Becker and Egger (2007) for West German firms or Garcia et al. (2002) for a set of Spanish firms. In contrast, Ross and Zimmermann (1993) in their study on German manufacturing firms point to the destructive effect of process innovations while Van Reenen (1997) for UK manufacturing firms, Rottmann and Ruschinski (1998) for West German firms or Hall, Lotti, and Mairesse (2008) for a panel of Italian firms find no significant effect of process innovations on firm-level employment.

6 See, e.g., Van Reenen (1997), Smolny (1998), Rottmann and Ruschinski (1998), Lachenmaier and Rottmann (2006), Zimmermann (2008), Piva and Vivarelli (2005), Hall, Lotti, and Mairesse (2008) or Harrison et al. (2014).

7 See Annex Table A.2 for summary statistics and Annex Tables A.3 and A.4 for correlation matrices of the main variables used in the estimations.

8 It refers to the annualized growth rate defined as follows: $\left(\frac{A\left(t_{0}\right)}{A\left(t_{-3}\right)}\right)^{1 / n}-1$, where $A\left(t_{0}\right)$ refers to the current $A\left(t_{-3}\right)$ value, refers to the value three years previously and $n=t_{0}-\left(t_{-3}\right)$

${ }^{9}$ A more thorough analysis (not presented here) demonstrates that this finding is entirely driven by developments and the employment changes of establishments located in Macedonia and Kosovo, which both avoided recessions during the crisis and postcrisis stress and where average annual employment growth rates were among the highest during the post-crisis period.

10 Test statistics reported in Table 1 and Table 2 generally demonstrate that the variable "product innovations" needs to be treated as endogenous (the endogeneity test is rejected for all specifications at the $1 \%$ or $5 \%$ level), that the instruments are valid (Sargan test is never rejected) and not weak (Stock-Yogo weakinstruments test is rejected) and that the specifications are identified (Anderson's likelihood ratio test is always rejected). 


\section{REFERENCES}

Aghion, P., Fally, T. and S. Scarpetta. 2007. Credit Constraints as a Barrier to the Entry and Post-Entry Growth of Firms. Paper prepared for the $45^{\text {th }}$ Panel Meeting of Economic Policy.

Aghion, P. and Howitt, P. 1992. A model of growth through creative destruction. Econometrica 60 (2): 323-351.

Álvarez, R. and Crespi, G. 2011. Financing Gaps, Innovation Gaps?: New Evidence from Chile. Paper presented the 2011 Globelics Conference.

Anderson, T. W. 1984. Introduction to Multivariate Statistical Analysis. 2nd ed. New York: Wiley.

Angelini, P. and Generale, A. 2005. Firm size distribution: do financial constraints explain it all? Evidence from survey data. Banca D'Italia Working Paper No. 549.

Ayyagari, M., Demirgüç-Kunt, A. and Maksimovic, V. 2008. How Important Are Financing Constraints? The Role of Finance in the Business Environment. The World Bank Economic Review 22 (3): 483-516.

Beck, T., Demirgüç-Kunt, A. and Maksimovic, V. 2006. The determinants of financing obstacles. Journal of International Money and Finance 25: 932-952.

Beck, T., Demirgüç-Kunt, A. and Maksimovic, V. 2005. Financial and Legal Constraints to Growth: Does Firm Size Matter? The Journal of Finance 60 (1): 137-177.

Beck, T., Demirgüç-Kunt, A. and Maksimovic, V. 2003. Bank competition, financing obstacles and access to credit. World Bank Policy Research Working Paper Series No. 2996.

Becker, S. O. and Egger, P. H. 2007. Employment Effects of Product and Process Innovations. Mimeo.

Bellak, C. 2004. How Domestic and Foreign Firms Differ And Why Does It Matter? Journal of Economic Surveys 18 (2): 1-32.

Bigsten, A. and Gebreeyesus, M. 2007. The small, the young, and the productive: Determinants of manufacturing firm growth in Ethiopia. Economic Development and Cultural Change 55(4): 813-840.

Clarke, G. R. G, Cull, R. and Martinez Peria, M. S. 2001. Does foreign bank penetration reduce access to credit in developing countries? Evidence from asking borrowers. World Bank Policy Research Paper No. 2716.

Coad, A. and Tamvada, J. P. 2008. The Growth and Decline of Small firms in Developing Countries. Max Planck Institute of Economics Papers on Economics and Evolution No. 0808.

De Serres, A., Kobayakawa, S., Slok, T. and Vartia, L. 2006. Regulation of financial systems and economic growth in OECD countries: An empirical analysis. OECD Economic Studies No. 43, 2006/2.

Demirgüç-Kunt, A. and Maksimovic, V. 1998. Law, Finance, and Firm Growth, Journal of Finance 53: 2107-2137.

Dollar, D., Hallward-Driemeier, M. and Mengistae, T. 2005. Investment Climate and Firm Performance in Developing
Economies. Economic Development and Cultural Change 54 (1): 1-31.

Dunne, T., Roberts, M. and Samuelson, L. 1989. The growth and failure of US manufacturing plants. Quarterly Journal of Economics 104 (4): 671-698.

Evans, D. S. 1987a. The relationship between firm growth, size and age: Estimates for 100 manufacturing industries. Journal of Industrial Economics 35: 567-581.

Evans, D. S. 1987b. Tests of alternative theories of firm growth. Journal of Political Economy 95 (4): 657-674.

Ferrando, A. and Mulier, K. 2013. Firms' Financing Constraints Do Perceptions Match the Actual Situation? European Central Bank Working Paper Series No. 1577.

Gallo, M., Cappuyns, K. and Tàpies, J. 2004. Comparison of Family and Nonfamily Business: Financial Logic and Personal Preferences. Family Business Review 17 (4): 303-318.

Garcia, A., Jaumandreu, J. and Rodriguez, C. 2002. Innovation and Jobs: Evidence from Manufacturing Firms. MPRA Paper, No. 1204.

Geroski, P. A. and Gugler, K. 2004. Corporate growth convergence in Europe. Oxford Economic Papers 56: 597-620.

Goldshmith, R. W. 1969. Financial structure and development. New Haven, CT: Yale University Press.

Grossman, A. and Helpman, E. 1991. Quality ladders in the theory of growth. Review of Economic Studies 58 (1): 43-61.

Hadlock, C. J. and Pierce, J. R. 2010. New Evidence on Measuring Financial Constraints: Moving Beyond the KZ Index. The Review of Financial Studies 23 (5): 1909-1940.

Hajivassiliou, V. and Savignac, F. 2008. Financing Constraints and a Firm's Decision and Ability to Innovate: Establishing Direct and Reverse Effects. Notes D'Édutes et de Recherche, NER - R \# 202.

Hake, M. 2009. Firm Growth and Ownership Change in CEE Countries. Austrian National Bank Working Paper.

Hall, B. H., Lotti, R. and Mairesse, J. 2008. Employment, Innovation, and Productivity: Evidence from Italian Microdata. Industrial and Corporate Change 17 (4): 813-839.

Haltiwanger, J., Scarpetta, S. and Schweiger, H. 2006. Assessing Job Flows across Countries: The Role of Industry, Firm Size and Regulations. World Bank Policy Research Working Paper No. 4070.

Hamelin, A. and Trojman, J. 2007. Family ownership and growth: The case of French SMEs. LARGE, Laboratoire de Recherche en Gestion et Economie Working Paper.

Harhoff, D., Stahl, K. and Woywode, M. 1998. Legal form, growth and exit of West German firms - empirical results for manufacturing, construction, trade and service industries. The Journal of Industrial Economics 46 (4): 453-488

Harrison, R., Jaumandreu, J., Mairesse, J. and Peters, B. 2014. Does Innovation Stimulate Employment? A Firm-Level 
Analysis Using Comparable Micro-Data from Four European Countries. International Journal of Industrial Organization 35: 29-43.

Hasan, S. M. 2013. Credit Constraints, Technology Choice and Exports - A Firm Level Study for Latin American Countries. Selected Poster prepared for presentation at the Agricultural \& Applied Economics Association's 2013 AAEA \& CAES Joint Annual Meeting, Washington, DC, August 4-6, 2013.

Hashi, I. 2001. Financial and Institutional Barriers to SME Growth in Albania: Results of an Enterprise Survey. MOCT-MOST 11 (3): 221-238.

Hashi, I. and Krasniqi, B. A. 2011. Entrepreneurship and SME growth: evidence from advanced and laggard transition economies. International Journal of Entrepreneurial Behavior \& Research 17 (5): 456-487.

Héricourt, J. and Poncet, S. 2007. FDI and credit constraints: Firm-level evidence in China. CES Working Papers 2007.09.

King, R. G. and Levine, R. 1993. Finance and Growth: Schumpeter Might be Right. Policy Research Working Papers WPS 1083, The World Bank.

Lachenmaier, S. and Rottmann, H. 2006. Employment Effects of Innovation at the Firm Level. IFO Working Papers.

Levine, R. and Zervos, S. 1998. Stock markets, banks, and economic growth. American Economic Review 88 (3): 537-558.

Liedholm, C. 2002. Small firm dynamics: Evidence from Africa and Latin America. Small Business Economics (18) 3: 227-242.

Lipsey, R.E., Sjöholm, F. and Sun, J. 2010. Foreign Ownership and Employment Growth in Indonesian Manufacturing. NBER Working Paper 15936.

Lucas, R.E. 1988. On the Mechanics of Economic Development. Journal of Monetary Economics 22: 3-42.

Mahérault, L. 2004. Is there Any Specific Equity Route for Small and Medium-Sized Family Businesses? The French Experience. Family Business Review 17 (3): 221-235.

Mancusi, M. L. and Vezzulli, A. 2010. R\&D and Credit Rationing in SMEs. Paper presented at the $38^{\text {th }}$ Annual Conference of the European Association for Research in Industrial Economics, Stockholm.

Männasoo, K. and Meriküll, J. 2011. R\&D, Demand Fluctuations and Credit Constraints: Comparative Evidence from Europe. Eesti Pank Working Paper Series No. 5/2011.

McPherson, M. A. 1996. Growth of micro and small enterprises in southern Africa. Journal of Development Economics 48: 253-277.

Mead, D. C. and Liedholm, C. 1998. The Dynamics of Micro and Small Enterprises in Developing Countries. World Development 26 (1): 61-74.
Minetti, R. and Zhu, S. C. 2011. Credit constraints and firm export: Microeconomic evidence from Italy. Journal of International Economics 83: 109-125.

Mohnen, P., Palm, F. C., Schim van der Loeff, S. and Tiwari, A. 2008. Financial Constraints and Other Obstacles: Are they a Threat to Innovation Activity? UNU-MERIT Working Paper Series No. 208-006.

Molly, V., Laveren, E. and Deloof, M. 2010. Family Business Succession and Its Impact on Financial Structure and Performance. Family Business Review 23 (2): 131-147.

Nichter, S. and Goldmark, L. 2009. Small Firm Growth in Developing Countries. World Development 37 (9): 1453-1464.

Oberhofer, H. 2010. Firm growth, European industry dynamics and domestic business cycles. FIW Working Paper No. 55.

Petkova, N. 2008. Does Foreign Shareholding Improve Firm Operating Performance? Paper presented at the Financial Management Association-Conference 2008, downloaded from http://www.fma.org/Reno/Papers/ FDI_and_firm_performance.pdf (August, 2015).

Piva M. and Vivarelli, M. 2005. Innovation and Employment: Evidence from Italian Microdata. Journal of Economics 86 (1): 65-83.

Popov, A. 2013. Credit Constraints and Investment in Human Capital Training Evidence from Transition Economies. ECB Working Paper Series No. 1606.

Rajan, R. G. and Zingales, L. 1998. Financial Dependence and Growth. American Economic Review 88: 559-586.

Robinson, J. 1952. The rate of interest, and other essays. London: Macmillan.

Romer, P. M. 1990. Endogenous Technological Change. Journal of Political Economy 98 (5): S71-S102.

Ross, D. R. and Zimmermann, K. 1993. Evaluating Reported Determinants of Labour Demand. Labour Economics 1: 71-84.

Rottmann, H. and Ruschinski, M. 1998. The Labour Demand and the Innovation Behaviour of Firms. Jahrbücher für Nationalökonomie und Statistik 217 (6): 741-752.

Scarpetta, S., Hemmings, R., Tressel, T. and Woo, J. 2002. The Role of Policy and Institutions for Productivity and Firm Dynamics. OECD Economics Department Working Papers, No. 329, OECD Publishing.

Schiantarelli, F. and Sembenelli, A. 2000. Form of ownership and financial constraints: Panel data evidence from flow of funds and investment equations. Empirica 27: 175-92.

Schumpeter, J. A. 1912. Theorie der Wirtschaftlichen Entwicklung [The theory of economic development], Leipzig: Dunker \& Humblot, 1912; translated by REDVERS OPIE, Cambridge, MA: Harvard University Press, 1934.

Serti, F., and Tomasi, C. 2008. Self-selection and post-entry effects of exports: Evidence from Italian manufacturing firms. Review of World Economics 144: 660-694. 
Shin, H. H. and Park, Y. S. 1999. Financing constraints and internal capital markets: Evidence from Korean 'chaebols'. Journal of Corporate Finance 5: 169-91.

Sleuwaegen, L. and Goedhuys, M. 2002. Growth of firms in developing countries, evidence from Côte d'Ivoire. Journal of Development Economics 68 (1): 117-135.

Smolny, W. 1998. Innovations, Prices and Employment - A Theoretical Model and an Empirical Application for West-German Manufacturing Firms. Journal of Industrial Economics 46 (3): 359-381.

Solow, R. 1957. Technical change and the aggregate production function. Review of Economics and Statistics 39 (3): 312-320.

Stiglitz, J. E and Weiss, A. 1981. Credit Rationing in Markets with Imperfect Information." American Economic Review 71 (3): 393-410.

Stock, J. H. and Yogo, M. 2005. Testing for Weak Instruments in Linear IV Regression. In Identification and Inference for Econometric Models: Essays in Honor of Thomas J. Rothenberg, edited by J. H. Stock and D. W. K. Andrews, 80-108. Cambridge University Press.

Storey, D. J. 1994. Understanding the small business sector. London: Thomson Learning.

Tiwari, A. K., Mohnen, P., Palm, P. C. and van der Loeff, S. S. 2007. Financial Constraint and R\&D Investment: Evidence from CIS. UNU-Merit Working Paper Series No. 2007-011.

Van Reenen, J. 1997. Employment and Technological Innovation: Evidence from U.K. Manufacturing Firms. Journal of Labor Economics 15 (2): 255-284.

Variyam, J. N. and Kraybill, D. S. 1992. Empirical evidence on determinants of firm growth. Economics Letters 38: 31-36.

Veugelers, R. and Cassiman, B. 1999. Make and buy in innovation strategies: evidence from Belgian manufacturing firms. Research Policy 28 (1): 63-80.

Wagner, J. 2002. The causal effects of exports on firm size and labor productivity: first evidence from a matching approach. Economics Letters 77: 287-292.

Winker, P. 1999. Causes and Effects of Financing Constraints at the Firm Level. Small Business Economics 12: 169-181.

Zimmermann, V. 2008. The impact of innovation on employment in small and medium enterprises with different growth rates. ZEW Discussion Paper No. 08-134. 


\section{ANNEX}

Table A1: List of countries included in the analysis, by period

\begin{tabular}{lcccc}
\hline & Abbrev. & \multicolumn{3}{c}{ Number of establishments } \\
\cline { 3 - 5 } Country & Pre-crisis period & Post-crisis period & Total \\
\hline Bulgaria & CZ & 288 & 293 & 581 \\
Czech Republic & 250 & 143 & 393 \\
Estonia & EE & 273 & 273 & 546 \\
Hungary & HU & 291 & 310 & 601 \\
Lithuania & LT & 276 & 270 & 546 \\
Latvia & LV & 271 & 336 & 607 \\
Poland & PL & 455 & 542 & 997 \\
Romania & RO & 541 & 540 & 1,081 \\
Slovenia & SI & 276 & 270 & 546 \\
Slovakia & SK & 275 & 173 & 448 \\
Turkey & TR & 1,151 & 707 & 1,858 \\
Albania & AL & 175 & 360 & 535 \\
Bosnia and Herzegovina & BA & 361 & 360 & 721 \\
Croatia & HR & 159 & 360 & 519 \\
Montenegro & ME & 116 & 150 & 266 \\
Macedonia & MK & 366 & 360 & 726 \\
Serbia & RS & 388 & 360 & 748 \\
Kosovo & XK & 270 & 202 & 472 \\
\hline & Total & 6,182 & 6,009 & 12,191 \\
\hline
\end{tabular}


Table A2: Summary statistics

\begin{tabular}{|c|c|c|}
\hline & Pre-crisis & Post-crisis \\
\hline & Mean (Std.Dev) & Mean (Std.Dev) \\
\hline & [Min; Max] & [Min; Max] \\
\hline \multirow[t]{2}{*}{ Sales growth } & $38.45(90.5)$ & $14.6(65.3)$ \\
\hline & {$[-97.9 ; 979.5]$} & {$[-100 ; 995.5]$} \\
\hline \multirow[t]{2}{*}{ Employment growth } & $12.0(38.7)$ & $3.7(21.6)$ \\
\hline & {$[-89 ; 960.7]$} & {$[-75.8 ; 386.5]$} \\
\hline \multirow[t]{2}{*}{ FC-Total } & $0.2(0.4)$ & $0.2(0.4)$ \\
\hline & {$[0 ; 1]$} & {$[0 ; 1]$} \\
\hline \multirow[t]{2}{*}{ FC-Rejected } & $0.1(0.3)$ & $0.1(0.3)$ \\
\hline & {$[0 ; 1]$} & {$[0 ; 1]$} \\
\hline \multirow[t]{2}{*}{ FC-Constrained } & $0.3(0.4)$ & $0.23(0.4)$ \\
\hline & {$[0 ; 1]$} & {$[0 ; 1]$} \\
\hline \multirow[t]{2}{*}{ Balkan } & $0.3(0.5)$ & $0.4(0.5)$ \\
\hline & {$[0 ; 1]$} & {$[0 ; 1]$} \\
\hline \multirow[t]{2}{*}{ Balkan*FC-Total } & $0.1(0.3)$ & $0.1(0.3)$ \\
\hline & {$[0 ; 1]$} & {$[0 ; 1]$} \\
\hline \multirow[t]{2}{*}{ Balkan*FC-Rejected } & $0.1(0.2)$ & $0.0(0.2)$ \\
\hline & {$[0 ; 1]$} & {$[0 ; 1]$} \\
\hline \multirow[t]{2}{*}{ Balkan*FC-Constrained } & $0.1(0.3)$ & $0.1(0.3)$ \\
\hline & {$[0 ; 1]$} & {$[0 ; 1]$} \\
\hline \multirow[t]{2}{*}{ Log age } & $2.6(0.7)$ & $2.7(0.6)$ \\
\hline & {$[0 ; 5.2]$} & {$[0 ; 5]$} \\
\hline \multirow[t]{2}{*}{$\log _{\text {age }}{ }^{2}$} & $7.0(3.8)$ & $7.3(3.2)$ \\
\hline & {$[0 ; 27.1]$} & {$[0 ; 25.2]$} \\
\hline \multirow[t]{2}{*}{ Log size } & $3.4(1.5)$ & $2.9(1.3)$ \\
\hline & {$[0 ; 9.6]$} & {$[0 ; 9]$} \\
\hline \multirow[t]{2}{*}{$\log _{\text {size }}^{2}$} & $13.7(11.5)$ & $10.1(9.1)$ \\
\hline & {$[0 ; 92.5]$} & {$[0 ; 81.7]$} \\
\hline \multirow[t]{2}{*}{ Log years of experience TM } & $2.8(0.7)$ & $2.8(0.6)$ \\
\hline & {$[0 ; 4.1]$} & {$[0 ; 4.1]$} \\
\hline \multirow[t]{2}{*}{ Foreign ownership share } & $8.5(26.1)$ & 7.7 (25.3) \\
\hline & {$[0 ; 100]$} & {$[0 ; 100]$} \\
\hline \multirow[t]{2}{*}{ State ownership share } & $1.1(7.8)$ & $0.4(5.1)$ \\
\hline & {$[0 ; 99]$} & {$[0 ; 99]$} \\
\hline \multirow[t]{2}{*}{ Exporter only } & $0.2(0.4)$ & $0.2(0.4)$ \\
\hline & {$[0 ; 1]$} & {$[0 ; 1]$} \\
\hline \multirow[t]{2}{*}{ Importer only } & $0.1(0.2)$ & $0.1(0.2)$ \\
\hline & {$[0 ; 1]$} & {$[0 ; 1]$} \\
\hline \multirow[t]{2}{*}{ Exporter \& importer } & $0.1(0.3)$ & $0.1(0.3)$ \\
\hline & {$[0 ; 1]$} & {$[0 ; 1]$} \\
\hline \multirow[t]{2}{*}{ Big City } & $0.4(0.5)$ & $0.2(0.4)$ \\
\hline & {$[0 ; 1]$} & {$[0 ; 1]$} \\
\hline Real GDP growth rate & $6.3(1.8)$ & $1.9(2.1)$ \\
\hline & {$[1.6 ; 10.9]$} & {$[-1.7 ; 6.7]$} \\
\hline Paying taxes & $63.45(12.6)$ & $67.6(11.6)$ \\
\hline & {$[44.6 ; 84.9]$} & {$[48.9 ; 82.1]$} \\
\hline Starting a business & $78.1(8.3)$ & $86.5(7.9)$ \\
\hline & {$[60.3 ; 90.8]$} & {$[62.4 ; 96.1]$} \\
\hline Resolving insolvency & $34.9(11.1)$ & $38.8(9.9)$ \\
\hline & {$[19.9 ; 54.4]$} & {$[24 ; 60.3]$} \\
\hline Dummy: Manufacturing & $0.4(0.5)$ & $0.4(0.5)$ \\
\hline & {$[0 ; 1]$} & {$[0 ; 1]$} \\
\hline Dummy: Construction & $0.1(0.3)$ & $0.1(0.3)$ \\
\hline & {$[0 ; 1]$} & {$[0 ; 1]$} \\
\hline
\end{tabular}

Source: BEEPS 2013, own calculations. 


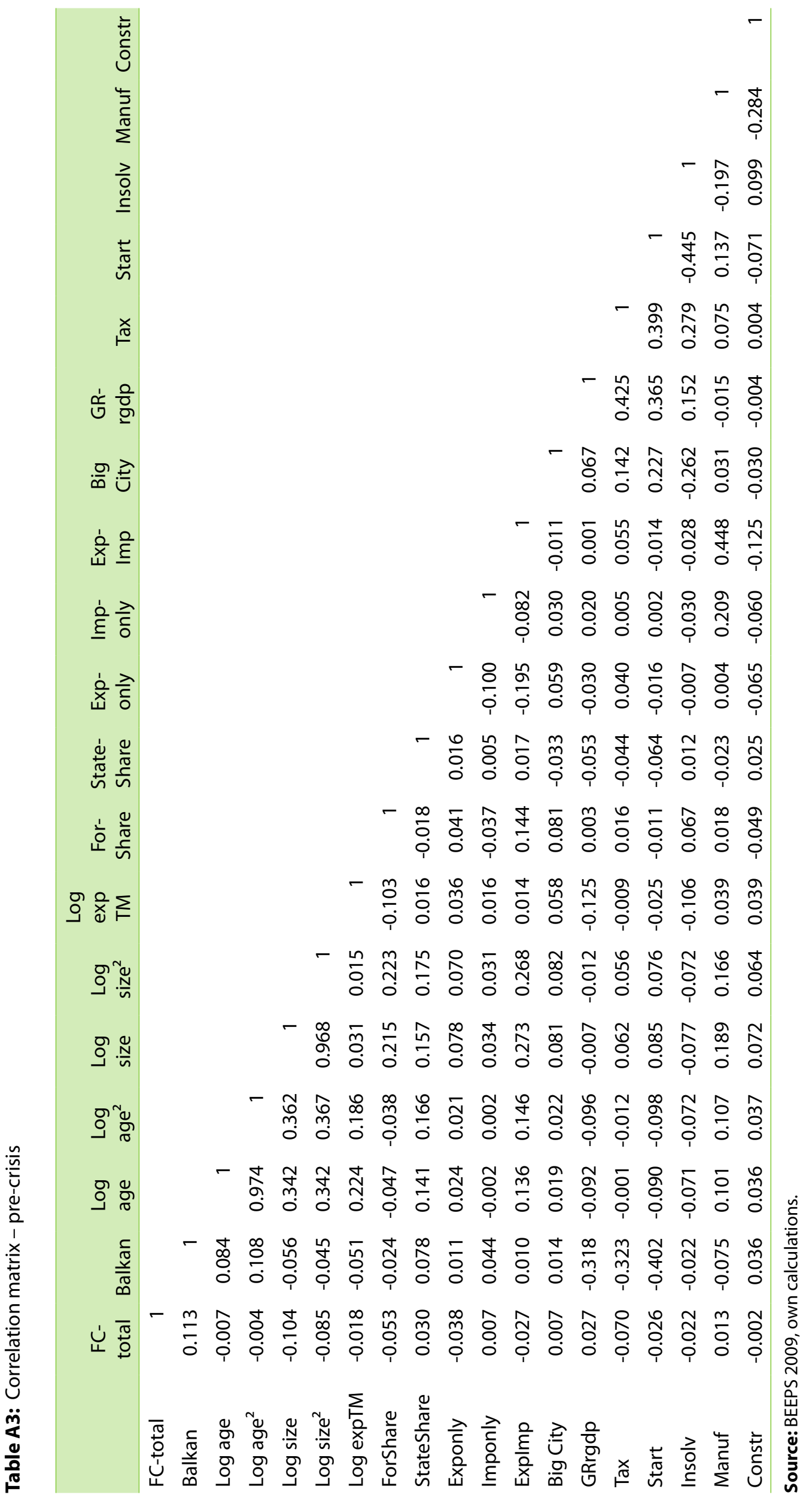




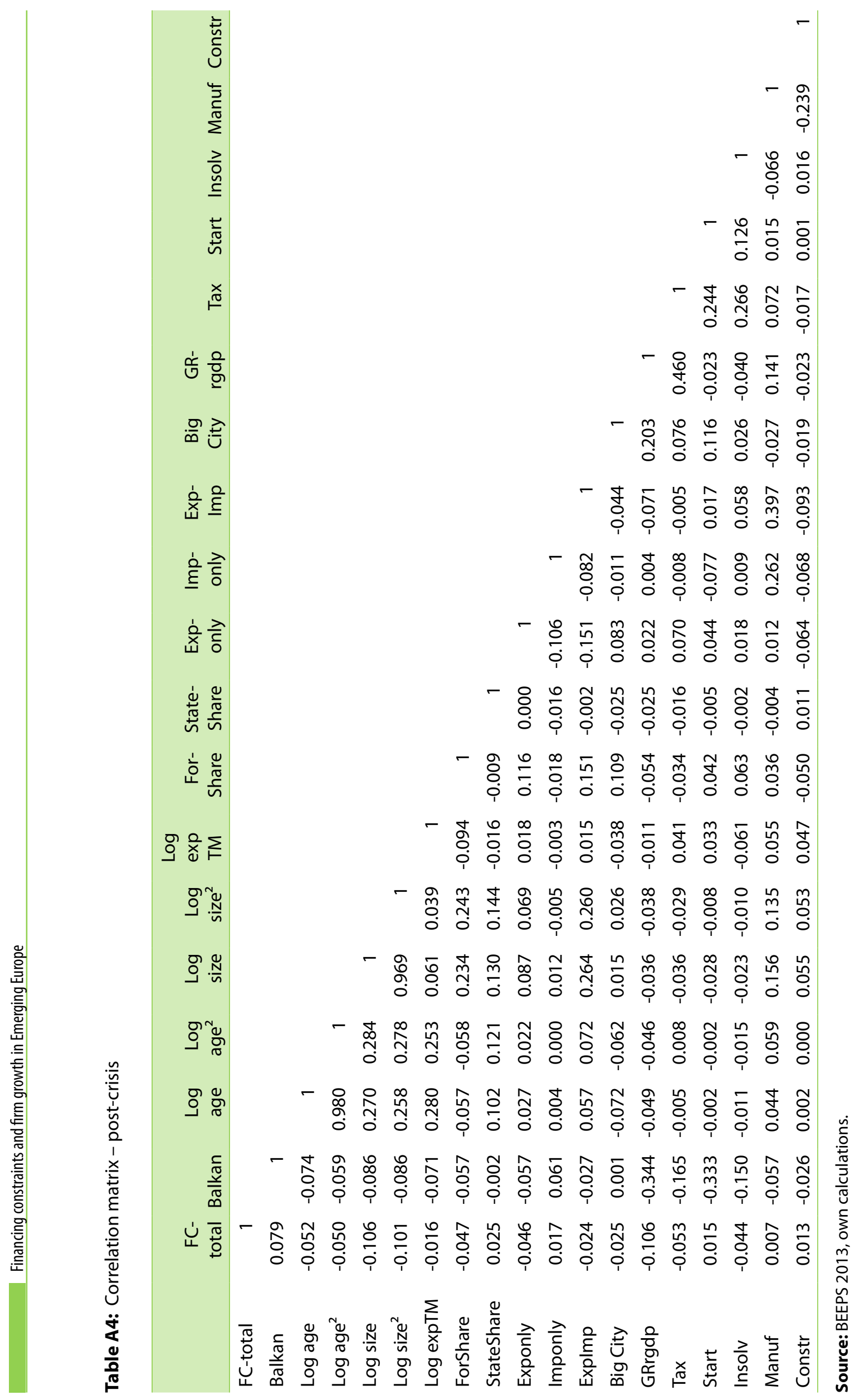

